\title{
Housing Typologies and Appropriation of the Urban Form in Alvalade's Neighborhood, Lisbon
}

\author{
Sofia Barroco \\ Architecture Faculty, Technical University of Lisbon, Agualva 2735-431, Portugal
}

\begin{abstract}
The Alvalade's neighborhood (Lisbon, Portugal), 1945, as a paradigm of Portuguese urbanism, can be distinguished by different housing cells that define it, as well as the different urban models, which relied on. It is possible to identify distinct occupational stains within the neighborhood, specifically in the cell one in this article, as a pioneer construction, due to housing dimension that corresponds to different housing typologies, residents and daily use areas, equipment. The objective is therefore, to understand how these three factors are reflected inside the cell, managing occupational stains which differ in space appropriation. How those different occupational stains that derive from the housing and urban morphology, may result in the occupation and experience of its inhabitants, not invalidating a cohesive structure of the neighborhood?
\end{abstract}

Key words: Housing morphology, appropriation of space, Alvalade.

\section{Introduction}

Alvalade (Lisbon, Portugal) with roots in the Urban Plan of the South Zone of Alferes Malheiro Avenue (Avenida Alferes Malheiro) in 1945 arises from necessity of restructuring and higher number of dwellings in the city of Lisbon, which was supported on the political regime of Estado Novo (1933-1974).

Not invalidating the efforts for creation and development of an architectural regime ${ }^{1}$, it can be said that the Alvalade's neighborhood arises and develops based on constant experimentation supported by several urban models with heterogeneous origins. Not making a reproduction of these models, but reinterpreting and articulating a set of concepts and techniques of the same, different experiences appear, while singular housing proposals that can maintain consistency while built set.

Corresponding author: Sofia Barroco, master architect, research fields: development of concepts, methodologies and tools focused at appropriation and use of space in the architecture, more specifically study of Alvalade's Neighborhoor, Lisbon, Portugal. E-mail: sofia.barroco@gmail.com.

${ }^{1}$ Architecture of the Estado Novo Regime or "Portuguese Soft Style”, as it is known, was adopted by the Salazar regime intended to apply to public works, to convey an architectural monumentality, emblazon the state and was "genuinely Portuguese”.
Based in the search for an ideal of urban space with housing characteristics were created distinct of housing. Were distributed different housing types within each cell, predicting the coexistence between housing searched and the different social strata.

The study of minimum areas in a house, and the provision of activities and consequent adaptation of the unit housing to its function, there are nine types based on different plans, which correspond to render economic collective, the first housing being implemented and combined with the pre-existence, to which are added later modernist buildings, generating an urban transformation in the Lisbon area. The variety of buildings and housing typologies projected at different times, and their spatial relationship and formal, allow the experience inside the neighborhood as a functional unit.

Based on the set of architectural and sociological references and sociological data available [1] which cover the residents and users, it is possible for people to identify different occupational spots, both as will involve the size housing as areas of daily use, equipment for highlighting therefore, the cell one, a pioneer of the neighborhood.

The main objective is to understand how distinct housing spots reflect and distribute spatially, having a 
sense of the intensity of the appropriation of space by the inhabitants and users of the cell.

\section{Cell One: Housing Typologies, Equipment and Residents}

Considering that fits into an extensive context of the city as individualized great work in shape and space [2], the method used in the projection of Alvalade neighborhood (Lisbon, Portugal), As is shown in Fig. 1, it is relapsed in the division of the available area in eight housing cells.

One of the bases of urbanization plan of Alvalade includes different housing typologies around a school equipment, which is the central nucleus of the cell.

The cell one (Fig. 1), while first cell designed and built, is bounded by Brazil Avenue (Avenida do Brasil) by north, Campo Grande to the east, Rome Avenue (Avenida de Roma) by west and Church Avenue (Avenida da Igreja), south, with a primary school while central core.

Characterized by traditional city, the organization of space is generated continuously with concepts of corridors streets, buildings and perspective, the structural concept of "culs-de-sac" of French origin, and the functional zoning, while modernist concept which provided separation of areas according to the various functions [3], this result in cell 1 (one).

Composed exclusively by housing units, while the equipment and services were installed later on lower floors of buildings, cell 1 (one) stands out not only as the first to be built, but above all, the first in which were applied principles relating to dwelling, equipment and resident population.

\subsection{Housing Typologies}

At the same time with the pre-existing buildings (built before the urbanization plan, many were those who remained or were replaced by new buildings) were designed in Alvalade houses of various categories.

In the first construction corresponding to cell 1 (one) were constructed of the following types:

(1) buildings of economic rent;

(2) buildings of not limited rent.

At that later came to join buildings with modernist character.

Were designed buildings of economic income and not limited rent as well as modernist. The housing typologies of economic rent as the example in Fig. 2, on the study of the architect Jacobetty Rosa, followed principles of zoning of domestic functions and taking into account the controlled cost of the same, were intended to be aimed at different social groups.

With a construction that respected the concept of "cul-de-sac" ${ }^{2}$, the cell 1 (one) is typologically distributed by four groups of dwellings, with a strong emphasis on the concept of neighborhood ${ }^{3}$, where the number of buildings of economic rent stands out from other groups by focusing in the interior of cell 1 (one), while the rest are distributed around the periphery thereof.

\subsection{Equipment}

The lifting equipment everyday places went through the following steps:

(1) its nature (four groups: business, health, religious, school, etc.);

(2) number (the number of devices dispersed throughout the cell);

(3) location (determining the exact level of spatial positioning of each of the equipment).

\footnotetext{
2 "Cul-de-sac" is an expression of French origin that means "dead end", originating from the planning of cities before the advent of the automobile. While typological solution lies in urban design complementary to the process of local circulation, whose arrangement of buildings creates small residential areas, with residential units on both sides of the track and at the top, forming itself via a " $\mathrm{T}$ " and ending the impasse, while the built is disposed in a " $U$ ".

3 The concept of neighborhood unit, extensively applied in Alvalade Neighborhood (Lisbon, Portugal), put on the socio-spacial integration with different housing types in order to avoid segregation and excessive traffic in areas of community life, focusing thereby social relations between neighboring cells, bucking the trend that has been watching removal and consequent disappearance of relationship between them.
} 

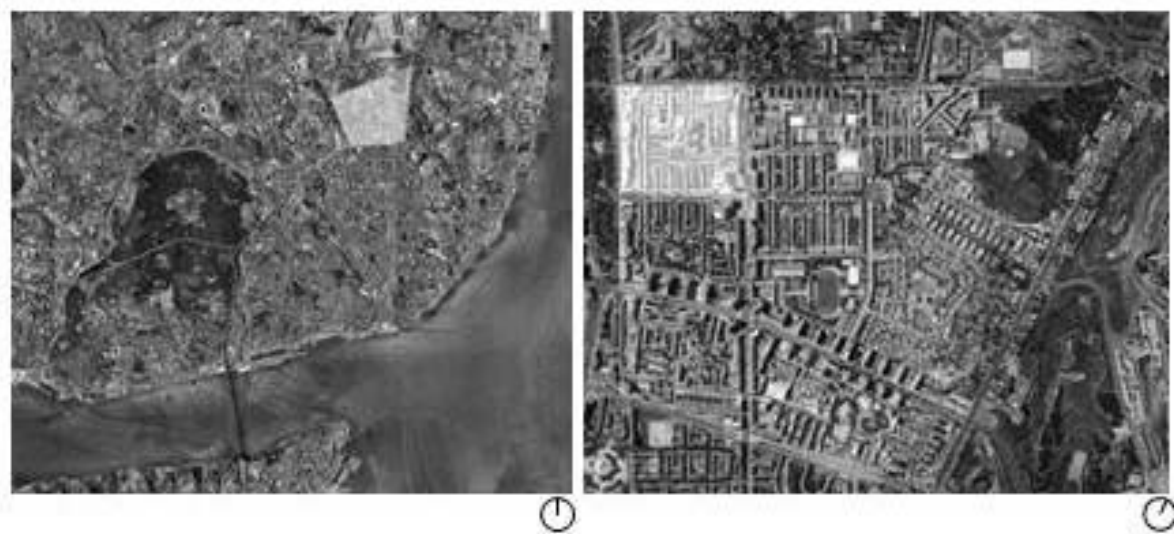

Fig. 1 Alvalade's neighborhood in Lisbon and cell one inside the neighborhood.

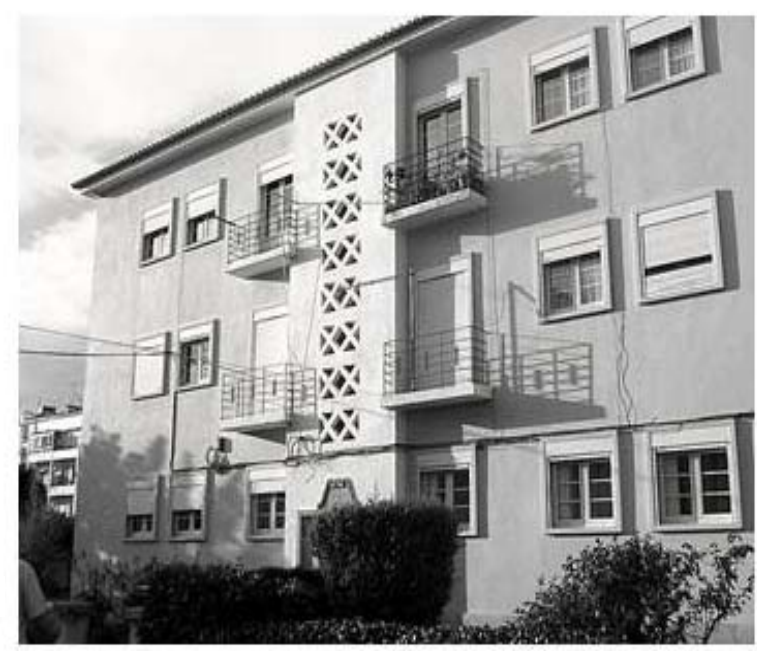

Fig. 2 Typology of economic house.

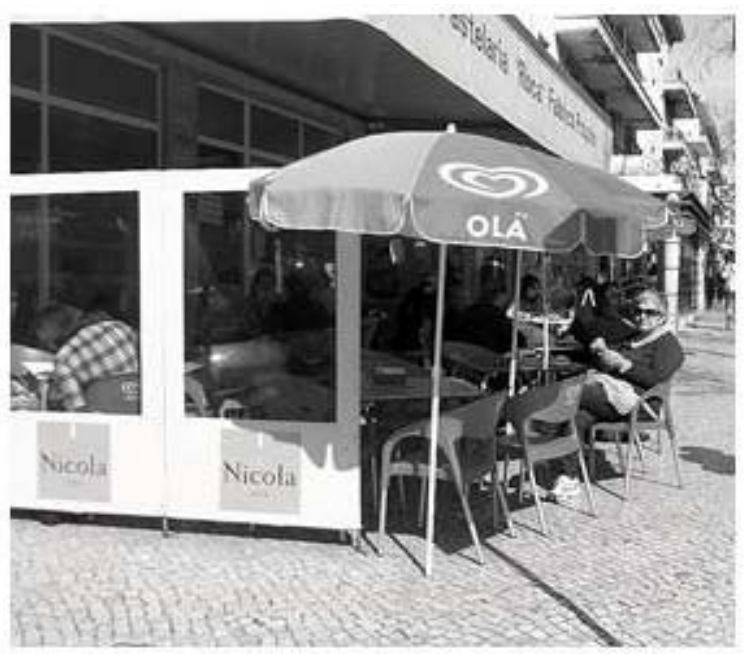

Fig. 3 Example of equipment for daily use—sidewalk café.

Result of this survey, a systematic data through the listing and spatial location of each piece of equipment, allows people to verify that the vast majority are distributed in the periphery of the cell, following the main access roads (Fig. 3) that structure and define it by providing daily support the inhabitants and external users, with the exception of school equipment (primary school).

Gonçalves [4] argues that in the broad sense, the residential neighbourhood is grouped near the main crossroad, as seen in Alvalade.

\subsection{Residents}

In an universe of 3,685 residing in cell one, it was found that the number of population increases significantly the periphery therefore. As observed previously the different groups of housing typologies are distributed by cell in the same way, once pre-existing buildings, it will be not limited rent and modernist buildings comprise the cell periphery, while the economic rent complete the central nucleus of the cell.

In this way, it is not possible to make an association between the number of residents and housing typologies, since the first ones choose to inhabit areas with higher typological diversity regarding to the housing configuration. It is defended once again that this could happen due to location on the periphery of the cell, taking into account the morphology of the space, and the main routes that structure and define the different spaces of Alvalade's neighborhood. Spaces that possess besides stores and seats have large walks where people can relax and chat as can be seen 
in Fig. 4.

\section{Appropriation of Space-Cell One}

With the basic notion that the neighborhood sees itself as a social entity and space [5], and that cell 1 (one) is part of Alvalade neighborhood (Lisbon, Portugal), it is possible to check different spots occupational compromising the appropriation of space thereof. This was possible through the systematization and overlap of data that have been mentioned: housing typologies, equipment and residents.

Residents and equipment for daily use tend to settle in greater numbers in areas spatially privileged due to the proximity of the main axes of structural neighborhood. The periphery around these axes emerges as the most favored and accessible area and greater number of access and transport to all parts of the city, communicating with the rest of surroundings.

After the overlap of the data mentioned above, regarding housing typologies, equipment and residents of cell one of Alvalade's neighborhood, it is possible to see what the different occupational stains (as can be shown in Fig. 5) which form the cell and making up the appropriation of the same space.

Residents and equipment of daily use tend to settle in more privileged areas spatially, due to proximity to the main structural axes of the neighborhood. These areas are benefited because they are more accessible, with more access and transport to all parts of the city and by having greater communication with the rest of surroundings. As a result, the overlap of these two types of data, allows people to obtain more intense occupational stains to north, east and west periphery of the cell concerned.

The housing typologies had already previously verified that there were four groups of constructions, since the pre-existing ones, through the economic rent, not limited and finally modernist buildings. Of the four, the types that appear in greater number are the buildings of economic rent, being located mainly in the center of the cell.

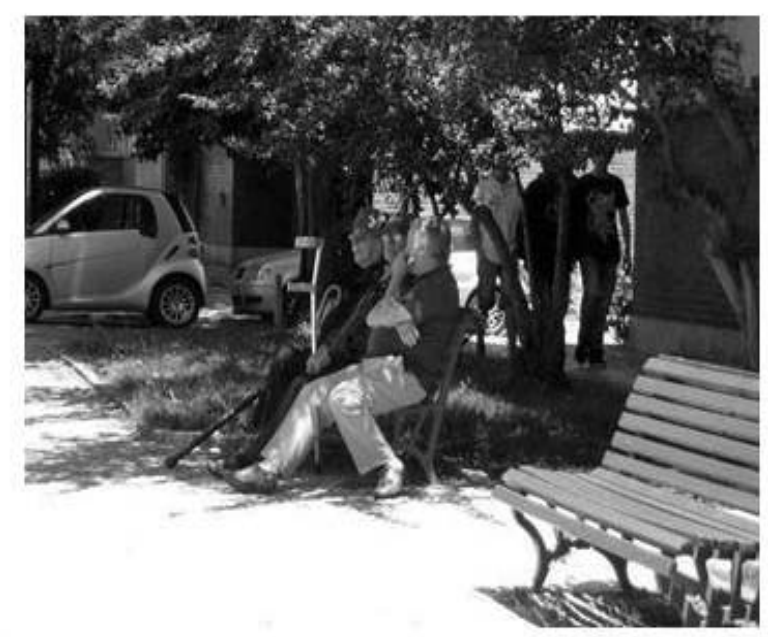

Fig. 4 Residents in a place of leisure-periphery of the cell.

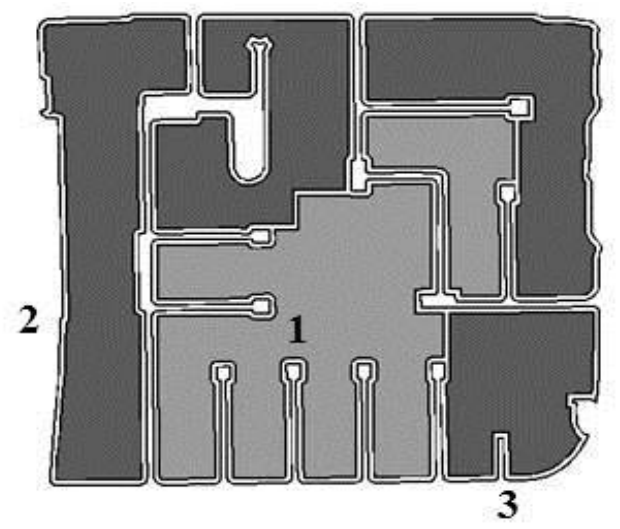

Increased number of equipment and residents Increased number of economic rent houses

Fig. 5 Occupational stains in cell one.

It is obtained in these way two distinct occupational stains: one corresponding to the periphery of the cell and which identifies larger number of residents and equipment, other daily use which corresponds to the central core of the cell, which is occupied by the largest number of housing typologies of economic rent.

It is speculated that residents searched their houses due to the location and not concerned to the housing typology, since the periphery receives the largest number of heterogeneous dwellings in the cell [6], it is impossible to choose a most frequent type according to the number of residents.

Equipment in turn, while opening local public, were 
made by inserting strategically along the main road axes that define the cell one, thereby serving not only the residents therefore, but also users who pass through it daily, or only for work, leisure or just in daily commuting, allowing greater affluence in these equipment because they are in a privileged location.

The central area of the cell is distinguished by their housing dimensions, whose economic rent (except the scholar nucleus) predominates and accentuate the neighborhood unit thanks to their morphological structure, as originally planned. The periphery in turn, becomes more relevance for the high number of residents who choose to live at the extremes of the cell and the areas of daily use, the equipment they are also distributed in these areas. Thus, it is formed two distinct occupational stains, the periphery of the cell, in which overlies the largest number of residents and equipment and the central, which is the largest number of housing typologies of the same constructive type-the economic rent.

Rapoport [7] says, "neighborhoods are one particular type of setting or, more correctly, one particular organization of a system of settings." Not invalidating the cohesive structure of the neighborhood as a functional unit, the dialogue between diverse needs results in different occupational stains that lead to distinct appropriation of space by its users.

\section{Conclusions}

As result of the study performed in this article, it is concluded that there is a direct relationship between housing typologies and the number of residents and daily use equipment. It was observed that in addition to the equipment if they have disseminated in periphery of the cell, the largest number of residents also inhabits this area, highlighting areas north, east and west of it, making occupational stains of central nucleus and south. The equipments were installed in order to become accessible, being located in the main arteries and structuring the cell, so possibly there is a housing preference for these same areas due to its geographical location, associated with accessibility to the detriment of housing typologies.

The conclusion is in this way that the cell one of the Alvalade's neighborhood consists of distinct occupational stains that differ from the periphery to the interior of the cell, relating directly to the main roads and not with the different housing typologies.

\section{References}

[1] 2001 Censuses, National Institute of Statistics of Portugal, Lisbon, 2001.

[2] A. Rossi, The Architecture of the City, Cosmos, Lisbon, 2001. (in Spanish)

[3] L. Corbusier, Principles of Urbanism-The Letter of Athens, Planeta-Agostini, Berlin, 1986. (in Spanish)

[4] A.C. Gonçalves, Urban Neighborhoods as Places of Social Practices, http://ler.letras.up.pt/uploads/ficheiros/1547.pdf (Accessed Jan. 1, 2013). (in Spanish)

[5] A. Rapoport, Neighborhood, Heterogeneity or Homogeneity, The Field of Man-Environment Studies, Department of Architecture, University of Wisconsin-Milwaukee, USA, 1980, p. 3.

[6] J.P. Costa, Alvalade's neighborhood: Urban housing considerations, Lisbon Technical University 1 (1997) 1-126. (in Spanish)

[7] A. Rapoport, House Form and Culture, Prentice-Haill Inc., Englewood Cliffs, USA, 1980, p. 4. 